\title{
How Effective Are Indiana's New Principals? \\ Implications for Preparation and Practice
}

\author{
Lori G. Boyland \\ Department of Educational Leadership \\ Teachers College $9^{\text {th }}$ Floor \\ Ball State University \\ Muncie, Indiana 47306 \\ lgboyland@bsu.edu
}

Lynn E. Lehman

Shawn K. Sriver

\begin{abstract}
This study investigates the performance of Indiana's new principals per the Educational Leadership Constituent Council (ELCC) and the Indiana Content Standards for building-level leader preparation. Using quantitative survey methodology, information was collected from Indiana superintendents regarding the effectiveness of principals who had recently completed university administrative preparation programs. Analysis of responses revealed that superintendents viewed their new principals as "proficient" in almost every area, with the highest mean observed in the category of Integrity. In contrast, the mean response for "financial management" was found to be in the "basic" range, creating implications for an area of potential development in school leadership education in the state.

\section{Introduction}

Research documents that effective school principals make a positive difference in student achievement and overall school success (Branch, Hanushek, \& Rivkin, 2013; Leithwood, Seashore, Anderson, \& Wahlstrom, 2004; Marzano, Waters, \& McNulty, 2005; Rice, 2010). However, there are concerns that university administrative training programs are irrelevant and inadequate in preparing candidates for the real world of public school leadership (Cowie \& Crawford, 2007; Hess \& Kelly, 2005, LaPointe \& Davis, 2006; Levine, 2005). In light of these concerns, the purpose of this study was to examine the effectiveness of Indiana's recently hired principals, as seen through the eyes of their superintendents, based on the Educational Leadership Constituent Council Standards (2011) and the Indiana Content Standards (2010) for building-level leaders. In Indiana, a Master's degree comprised of a standards-based leadership preparatory program is required in order to receive a building-level administrator's license, which is a requisite for employment as a public school principal (Indiana Department of Education [IDOE], 2013a). By investigating the performance of new principals, we explored an area recommended in the National Leadership Education Research Agenda 2013-2018 (NLERA), Priority II, Program Assessment and Evaluation, with a focus on shared standards for leadership programs (Andenoro et al., 2013). Our goal was to advance the field of leadership
\end{abstract}


education by providing information that might prove useful in improving and further developing university preparation programs for school leaders in Indiana.

\section{Background}

In her 2007 presidential address to the History of Education Society, Kate Rousmaniere remarked that of the many organizational changes that occurred in education around the turn of the twentieth century, few had greater impact than the development of the building principal. Early descriptions of the principal's role are that of a middle manager: a person who attends to the operational aspects of the school (Rousmaniere, 2007). But this image changed quickly. Cuban (1988) wrote that since the 1920s, the principal has been viewed as an instructional leader. He penned the popular aphorism, "as in the principal, so is the school," which signaled that the principal's behavior shaped how teachers and students performed (p. 61).

Decades later, on the threshold of the effective schools movement, Brookover and Lezotte (1977) explained that in improving schools, the principal was more likely to be an instructional leader, more assertive in his or her institutional leadership role, more of a disciplinarian, and perhaps most of all, responsible for students' achievement of basic objectives. In 1978, Berman and McLaughlin noted that educational innovations were more successful when supported by the building principal. Additional confirmation regarding the importance of the building principal was provided by Edmonds (1979) who reported that one of the most tangible and indispensable characteristics of an effective school was strong administrative leadership capable of bringing together the disparate elements of good schooling.

During the next several decades, various research studies added evidence to the argument that the building principal was an important variable in the school improvement formula. In 1987, Murphy and Hallinger suggested that an array of information had emerged that acknowledged the principal as a key factor in the improvement of schools. They described the school administrator as a significant force for change in organizational conditions and student outcomes. Milstein, Bobroff, and Restine (1991) argued that school reforms were dependent on, "site-based administrators who have vision, beliefs, abilities, and energy required to lead others toward shared objectives" (p. 2). In their synthesis of the research on principal effectiveness, Hallinger and Heck (1998) concurred, stating: "Schools that make a difference in student's learning are led by principals who make a significant and measurable contribution to the effectiveness of staff and in the learning of pupils in their charge" (p. 158). Other research findings from studies on educational reform conducted during the same era echoed the importance of the school principal in improving student achievement (Cowie \& Crawford, 2007; Duke, Grogan, Tucker, \& Heinecke, 2003; Tucker, Henig, \& Salmonowicz, 2005).

In 2002, Hill challenged the strength of the empirical relationship between principal effectiveness and student achievement. But as the reform movement, coupled with increased accountability, evolved into the $21^{\text {st }}$ century, researchers studying the impact of school leadership continued to publish more conclusive results. Leithwood et al. (2004) reported that leadership was second only to classroom instruction among school-related factors contributing to student learning and that the impacts of leadership accounted for about a quarter of total school effects.

Marzano et al. (2005) provided additional evidence by documenting the positive relationship between principal effectiveness and student achievement. Following their meta- 
analysis of 35 years of research they concluded that, “... school leadership has substantial effect on student achievement" (p. 12). More recently, Branch et al. (2013) discovered from their research in Texas that a highly effective principal raised the achievement of a typical student between two and seven months. Other researchers have added to this growing body of evidence linking school leadership and student achievement (Horng \& Leob, 2010; The Wallace Foundation, 2013).

However, even after decades of research, skeptics remain. Cowie and Crawford (2007) stated:

Despite the general consensus that the role of the school principal as both a manager and a leader matters and that preparation is important, there are considerable disagreements, often philosophical and political, about what kinds of principals are needed, what skills and attributes are needed and how they should be trained (p. 132).

Branch, Hanushek, and Rivkin (2009) pointed to a shortage of systematic research regarding the quantitative importance of principals. Other critics argued that increased research efforts have had negligible impact on school leader skill development in part because reform efforts have focused on the wrong thing (Frye, O’Neill, \& Bottoms, 2006; Hess \& Kelly, 2005; Norton, 2002). Murphy and Vriesenga (2004) concluded that little evidence exists that research conducted to date has had any noticeable impact on administrative practice. In some cases, there may even be a lack of support among practitioners for training of building-level leaders. In a 2001 survey, $69 \%$ of the principals polled agreed that, "The typical leadership programs in graduate schools of education are out of touch with the realities of what it takes to run today's school district" (Farkas, Johnson, Duffett, Foleno, \& Foley, 2001, p. 27). Eighty-five percent of the principals who responded to the survey agreed that overhauling graduate-level training would improve leadership in today's schools (Farkas et al., 2001).

The inability to isolate key relationships between a principal's leadership and student achievement may be due to the complexity of the role. The value of a principal can manifest itself in many ways, both directly and indirectly. Horng, Kalogrides, and Loeb (2009) remind us that effective principals can influence a variety of school outcomes. Rice (2010) proposed that effective principal behaviors resulted in greater teacher satisfaction, influenced where teachers worked, and shaped parents' perceptions about the schools their children attended, with the net result contributing to improved student academic performance. Hallinger concluded that the research on school improvement consistently found that skillful leadership of the principal contributed to successful change (2003). A 2013 report from The Wallace Foundation supports this position, "The real payoff comes when individual variables combine to reach critical mass. Creating the conditions under which that can occur is the job of the principal" (p. 5).

\section{In 2005, Marzano et al. published School Leadership that Works: From Research to} Results. The authors identified 21 responsibilities of a school leader. They acknowledged that their study did not identify new findings, but instead served to validate opinions expressed for decades by leadership theorists. This study was a milestone in the attempt to identify which leadership behaviors improved student achievement. Today, there appears to be a growing consensus that the following administrative practices lead to increased student achievement: setting direction, developing leadership in others, improving instruction, and redesigning the organization to prioritize student learning (Darling-Hammond, LaPointe, Meyerson, Orr, \& 
Cohen, 2007; Harvey \& Holland, 2012; Leithwood et al., 2004; Hill, 2002; The Wallace Foundation, 2013).

As the evidence for successful administrative practices has increased, so has the criticism of university training programs. Cowie and Crawford (2007) characterized preparation programs for principals as an "act of faith" (p. 129). Haller, Brent, and McNamara (1997) hypothesized that preparing highly effective principals required much more extensive training in school administration and concluded that graduate-level administrative training programs had little influence on the attributes that characterize effective schools. In his argument to "reculture" educational leadership, Murphy questioned not only the appropriateness of programs for preparing school leaders, but the legitimacy of the knowledge base supporting school administration (2001, p. 2). Levine was a harsh critic of administrator preparation programs when he characterized them as "... the weakest of all the programs at the nation's education schools" (2005, p. 13). Hess and Kelly wrote that, "Because preparation of principals has not kept pace with changes in the larger world of schooling, graduates of principal preparation programs have been left ill equipped for the challenges and opportunities posed by an era of accountability" (2005, p. 40). LaPointe and Davis (2006) synthesized current research by reporting that traditional methods of preparing school administrators fell short of providing the essential knowledge, skills, and dispositions that leaders needed to advance student learning in an increasingly diverse and complex society.

\section{Standards-Based Educator Preparation}

Various organizations and assessment strategies have served to form a baseline of expectations for educator preparation programs. One organization, The National Council for Accreditation of Teacher Education (NCATE) was founded in 1954 and has served as a primary organization for the establishment and maintenance of quality teacher and administrator preparation programs in the United States. In 2013, NCATE and TEAC (Teacher Education Accreditation Council) merged to become CAEP (Council for the Accreditation of Educator Preparation). Today there are over 650 accredited institutions nationwide that have voluntarily joined as one measure of assurance that educator training programs are of sufficient quality and relevance (CAEP, 2013).

Adherence to high quality educator preparation is grounded in the adoption of relevant and rigorous standards. For administrator preparation programs, the Educational Leadership Constituent Council (ELCC, 2011) or the Interstate School Leaders Licensure Consortium (ISLLC, 2008) represent the national standards commonly implemented (CCSSO, 2012; ELCC, 2011). Additionally, individual states often have their own adopted standards, as is the case in Indiana. There are four major university administrative training programs in Indiana, all of which follow the ELCC Standards and also the Indiana Content Standards for the preparation of school leaders (2010). Therefore, the ELCC Standards and the Indiana Content Standards are considered Indiana's "shared" standards for administrator preparation, serving accreditation purposes and also guiding best practice. 


\section{Context and Theoretical Framework}

There is increasing empirical evidence in support of the link between the principal's role and student achievement. However, this is countered by concerns over the quality of university administrator preparation programs, which provides the context and the catalyst for this study. Knowing that highly effective principals promote school success and that certain research-based skills, knowledge, and behaviors, as outlined in the ELCC Standards, are known to increase student achievement (Young \& Mawhinney, 2012), the question becomes: do recently hired school administrators possess these skills and knowledge? In Indiana, there has been a lack of research in this area and very little is known about the performance of new school leaders after they finish their required university preparation.

The ELCC Standards and Indiana Content Standards provided the framework for this study, with the Indiana Content Standards also integrated. Acceptable candidate performances for meeting ELCC standards are clearly outlined in terms of desired skills and knowledge, and universities are typically able to assess and track candidate's progress as they advance through their leadership education programs. However, after graduation, it becomes much more challenging to assess whether or not candidates have become effective school leaders. Educator preparation programs often have difficulty in obtaining reliable employment data from external sources and insufficient resources to locate and evaluate candidates' job performance after finishing university preparation.

\section{Purpose}

There are concerns regarding the relevance and effectiveness of university programs for the preparation of school leaders (Cowie \& Crawford, 2007; Hess \& Kelly, 2005, LaPointe \& Davis, 2006). Although the ELCC and Indiana Content Standards provide a solid framework for university educational leadership programs, there is a lack of follow-up on candidates in Indiana and very little information available regarding the performance of graduates once they are hired as administrators. The National Leadership Education Research Agenda calls for a deeper understanding of leadership education outcomes and recommends an exploration of shared standards for preparation programs (Anderono, 2013). Therefore, our purpose was to assess the effectiveness of Indiana's recently hired building-level leaders (principals and assistant principals), per the ELCC and Indiana Content Standards. Our guiding research question asked if Indiana's new administrators possessed the knowledge and skills that enabled them to be proficient building-level leaders. Our overriding goal was the collection of information that could be used to improve administrative preparation programs in order to better prepare school leaders.

\section{Methodology}

To address our research question, we determined that a quantitative survey methodology was most appropriate. We decided that feedback should be sought directly from the individuals responsible for hiring and evaluating Indiana's building-level leaders-- superintendents. Superintendents are vested with the responsibility of evaluating building-level administrators, who are required by state statute to have an annual performance evaluation (IDOE 2013a). The evaluation model proposed by the IDOE is standards-based and reflects a synthesis of research on effective leadership. 


\section{Survey Instrument}

We developed an electronic survey for superintendents using the platform Qualtrics (www.qualtrics.com). The survey first gathered basic demographic information about the school in which the new administrator was assigned, such as the school's grade levels, population characteristics, and type of school community (rural, suburban, or urban). Then, to determine performance levels regarding specific areas, the superintendent was asked to rate the new administrator on a series of standards-based questions using a four point Likert-type scale (1=Unsatisfactory, 2=Basic, 3=Proficient, 4=Distinguished). Superintendents could also select "Not Observed." In cases where "Not Observed" was selected, the responses were excluded from the analysis so that the mean was not impacted.

Following the demographic questions, there were 33 items designed to gather the superintendent's perceptions about the new administrator's effectiveness. The ELCC Standards and the Indiana Content Standards were condensed and integrated to develop all of these questions. The questions were clustered into seven categories: 1) Vision; 2) Culture, Instruction, Curriculum; 3) Management; 4) Collaboration; 5) Integrity and Ethics; 7) Social, Economic, Legal, and Cultural Context; and 8) General Leadership Questions.

Before implementation, we asked a panel experienced in survey development to review the survey and submit feedback regarding face and content validity. This six-member panel consisted of university faculty members, superintendents, and principals in the state of Indiana. Based on the panel's feedback, several revisions were made to wording and sequencing, which improved the survey's clarity and flow. The survey was then pilot tested with a similar panel with favorable results; therefore, no additional changes were made after the pilot tests.

\section{Procedure and Participants}

Administrative licensure is required in Indiana in order to serve as a public school principal, assistant principal, or other administrative position (IDOE 2013a). To earn a buildinglevel administrative license, a candidate must successfully complete a Master's degree in Educational Administration by participating in a university leadership preparation program. Indiana superintendents are keenly aware of these requirements, as they are held responsible for confirming administrative licensure upon hiring an employee. Our goal was to assess the effectiveness of recently hired administrators throughout Indiana, potentially shedding light on the strengths and weaknesses of university leadership preparation programs in the state.

There was no way to identify the specific school districts in Indiana with new administrators. Therefore, we invited every public school superintendent in the state to participate in the study. Following Institutional Review Board approval, we used the IDOE website (2013b) to gather the names and email addresses of the 289 current Indiana superintendents. In May of 2013, we sent an email with the survey link to all superintendents, asking them to complete a survey for each administrator hired who had completed a university leadership preparation program since 2009. Because we were interested in exploring the shared standards, not the individual university programs, we did not ask superintendents to specify which university the administrator had attended; however, we attempted to make it clear in the survey instructions that this was a study of Indiana's administrator preparation programs. The 
surveys were anonymous and no identifying information was requested. There were a total of 53 usable surveys returned, giving a response rate of $17 \%$, which Sheehan reports as acceptable for electronic surveys (2001).

\section{Results}

In the spring of 2013, we asked Indiana public school superintendents to complete a survey on the effectiveness of each new administrator. There were 53 responses; however, 15 of these were in reference to district-level administrators. For the purposes of this study, our focus was specifically building-level leaders. Therefore, we will be reporting on the 37 responses from superintendent regarding new building-level administrators.

\section{Demographics}

Superintendents were asked to provide demographic information about the new administrators and the schools where they were assigned. Of the 37 building-level leaders, $51.4 \%(n=19)$ were identified as principals, $43.2 \%(\mathrm{n}=16)$ as assistant principals, and 5.4\% $(n$ $=2$ ) as "other building-level administrative" positions. Because 35 of the 37 building-level leaders were assistant principals or principals, we refer to the group as "principals."

The grade levels of the principals' schools were evenly split with $48.6 \%(n=18)$ being elementary or intermediate-level schools, and $48.6 \%(n=18)$ being middle or high schools. There was one school (2.7\%) that housed all grades levels, K-12. The economic status of the schools, based on the percentage of students qualifying for free or reduced meals, indicated that $5.4 \%(n=2)$ had less than $20 \%$ qualifying, $51.4 \%(n=19)$ had $21-40 \%$ qualifying, $32.4 \%(n=$ 12) had $41-60 \%$ of students qualifying, and $10.8 \%(n=4)$ had $61 \%$ or above qualifying for meal assistance. The majority of the schools, $91.4 \%(n=34)$ enrolled $20 \%$ or less minority students, with $5.4 \%(n=2)$ enrolling $21-40 \%$ minority students, and one school $(2.7 \%)$ enrolling $61-80 \%$ minority students. The last demographic question, which was on community type, revealed that the majority of the schools were in rural areas $78.4 \%(n=29)$, with suburban at $16.2 \%(n=6)$, and urban at $5.4 \%(n=2)$. Overall, it was observed that the demographics of the schools and communities presented an accurate representation of Indiana in terms of typical population distributions and characteristics (U.S. Census Bureau, 2013). Indiana is primarily a rural state, with only 16 areas considered large "urban" (Indiana State Government, 2009).

\section{Standards-Based Skill and Knowledge Categories}

Superintendents were asked to rate principals as "Distinguished," "Proficient," "Basic," or "Unsatisfactory" on 33 questions that were developed using condensed ELCC Standard elements (2011) and the Indiana Content Standards (2010). Respondents were also given the option of answering "Not Observed," and these responses were removed before tabulation in order to prevent impacting the mean results. In the following paragraphs, the mean responses for each category will be briefly summarized, with tables presenting the complete results.

Vision. There were four questions in the Vision category, all related to the importance of effective leadership in the development, articulation, and promotion of school values and practices that fostered the success of every student. According to the superintendent respondents, Indiana's new principals are "proficient" in this category, with means ranging from 
2.85 to 3.21 . The highest mean response was seen in, "Using data to identify instructional goals for the purpose of improving student achievement" $(M=3.21, S D=0.74)$; and the lowest mean was observed in, "Conducting ongoing evaluation of progress towards school goals" $(M=2.85$, $S D=0.76)$. The overall mean for the Vision category was 3.01. Table 1 presents these results.

Table 1

Vision - Superintendents' Mean Responses Regarding the Performance of New Principals

Question $\quad n \quad M \quad S D$

\begin{tabular}{lccc}
\hline Promoting a commitment to school vision and goals & 33 & 2.94 & 0.70 \\
\hline $\begin{array}{l}\text { Using data to identify instructional goals for the purpose of } \\
\text { improving student achievement }\end{array}$ & 33 & 3.21 & 0.74 \\
\hline Promoting continual school improvement & 33 & 3.03 & 0.73 \\
\hline Conducting ongoing evaluation of progress toward school goals & 33 & 2.85 & 0.76
\end{tabular}

Note: 4 = Distinguished, 3 = Proficient, 2 = Basic, 1 = Unsatisfactory

Culture, instruction, and curriculum. This category asked superintendents four questions regarding new principals' abilities to sustain a positive school culture and instructional program that promotes student and staff learning. Overall, this was also seen as a positive area for the new school leaders, with means for all four questions above 3.00 and soundly in the "proficient" range. The highest mean observed was on the question, "Implementing technology to support school goals" $(M=3.12, S D=0.70)$. The overall mean response for this category was 3.09. These results are presented in Table 2.

Table 2

Culture, Instruction, Curriculum - Superintendents' Mean Responses Regarding the Performance of New Principals

\begin{tabular}{lccc}
\hline \multicolumn{1}{c}{ Question } & $n$ & $M$ & $S D$ \\
\hline Promoting a collaborative and caring school culture & 33 & 3.09 & 0.68 \\
\hline Leading the curricular and instructional programs & 33 & 3.06 & 0.70 \\
\hline $\begin{array}{l}\text { Demonstrating instructional skill through the utilization of best } \\
\text { practices }\end{array}$ & 33 & 3.09 & 0.77 \\
\hline Implementing technology to support school goals & 33 & 3.12 & 0.70 \\
\hline
\end{tabular}

Note: 4 = Distinguished, 3 = Proficient, 2 = Basic, 1 = Unsatisfactory 
Management. There were five questions in this category, which encompassed a school leader's skills in management, organization, and efficient operations of the school and resources in order to create an effective and safe learning environment. Mean responses on the majority of questions were in the "proficient" range; however, there was a low outlier in this category that fell in the "basic" range. This was, "Demonstrating financial management aligned with school goals" $(M=2.45, S D=0.87)$. Another question fell slightly below the norm of the means, "Developing leadership in others" $(M=2.73, S D=0.88)$. Conversely, there was one question that showed a higher mean response, "Maintaining the safety and welfare of students and staff" $(M=3.21, S D=0.65)$. The overall mean response for the Management category was 2.90, which was below both Vision and Culture. Table 3 summarizes these results.

Table 3

Management - Superintendents' Mean Responses Regarding the Performance of New Principals

\begin{tabular}{lccc}
\hline \multicolumn{1}{c}{ Question } & $n$ & $M$ & $S D$ \\
\hline Leading and supervising general operations of the school & 33 & 3.09 & 0.72 \\
\hline Demonstrating financial management aligned with school goals & 33 & 2.45 & 0.87 \\
\hline Maintaining the safety and welfare of students and staff & 33 & 3.21 & 0.65 \\
\hline Developing leadership in others & 33 & 2.73 & 0.88 \\
\hline Protecting instructional time & 33 & 3.03 & 0.68
\end{tabular}

Note: 4 = Distinguished, 3 = Proficient, 2 = Basic, 1 = Unsatisfactory

Collaboration. This category asked three questions related to a principal's ability to work effectively with faculty, families, community members, and community organizations to collaboratively promote student success and meet students' needs. However, as with Management, this category also showed slightly diminished means when compared to Vision and Culture. Although the questions' means still fell in the "proficient" range, all were below 3.00. The lowest mean was $2.75(S D=0.80)$ and this was on the question, "Working collaboratively with the community to meet students' needs." The overall mean response for the category of Collaboration was 2.88 , which was the lowest of any of the seven categories. These results are presented in Table 4. 
Table 4

Collaboration - Superintendents' Mean Responses Regarding the Performance of New Principals

\begin{tabular}{|c|c|c|c|}
\hline Question & $n$ & $M$ & $S D$ \\
\hline $\begin{array}{l}\text { Understanding and developing positive relationships with families } \\
\text { and the community }\end{array}$ & 33 & 2.97 & 0.81 \\
\hline $\begin{array}{l}\text { Understanding and promoting diversity and the values of } \\
\text { democracy }\end{array}$ & 33 & 2.91 & 0.58 \\
\hline $\begin{array}{l}\text { Working collaboratively with the community to meet students' } \\
\text { needs }\end{array}$ & 32 & 2.75 & 0.80 \\
\hline
\end{tabular}

Note: 4 = Distinguished, 3 = Proficient, 2 = Basic, 1 = Unsatisfactory

Integrity. There were four questions in this category related to a building-level leader's knowledge and skill in dealing with ethical issues, understanding moral consequences, and acting with integrity and fairness. Higher means were observed on three out of the four questions: "Modeling ethical behavior, fairness, and reflective practice" $(M=3.44, S D=0.50)$, "Understanding the moral and legal consequences of administrative decisions" $(M=3.38, S D=$ $0.66)$, and "Understanding and promoting social justice" $(M=3.22, S D=0.66)$. Overall this category revealed the highest mean response for any category, at 3.27; suggesting a strong area for new principals. These results are presented in Table 5.

Table 5

Integrity - Superintendents' Mean Responses Regarding the Performance of New Principals

\begin{tabular}{lccc}
\hline \multicolumn{1}{c}{ Question } & $n$ & $M$ & $S D$ \\
\hline $\begin{array}{l}\text { Ensuring a system of accountability for the success of every } \\
\text { student }\end{array}$ & 32 & 3.03 & 0.74 \\
\hline Modeling ethical behavior, fairness, and reflective practice & 32 & 3.44 & 0.50 \\
\hline $\begin{array}{l}\text { Understanding the moral and legal consequences of administrative } \\
\text { decisions }\end{array}$ & 32 & 3.38 & 0.66 \\
\hline Understanding and promoting social justice & 32 & 3.22 & 0.66 \\
\hline
\end{tabular}

Note: 4 = Distinguished, 3 = Proficient, 2 = Basic, 1 = Unsatisfactory 
Context - political, social, economic, legal, and cultural context. This category presented four questions regarding principals' understanding of the influence of context on schools as well as principals' abilities to promote positive change through proactive leadership. There was a broader range of mean responses in this category, from 2.66 to 3.28. The highest mean was observed on the question, "Creating positive opportunities for students" $(M=3.28, S D$ $=0.58$ ), and the lowest on "Informing stakeholders of current local state and national decisions affecting schools" $(M=2.66, S D=0.65)$. The overall mean response for this category was 3.07. Table 6 summarizes these results.

Table 6

Context (political, social, economic, legal and cultural) - Superintendents' Mean Responses Regarding the Performance of New Principals

Question $\quad n \quad M \quad S D$

\begin{tabular}{lccc}
\hline Advocating for students & 32 & 3.19 & 0.64 \\
\hline $\begin{array}{l}\text { Informing stakeholders of current local, state, and national } \\
\text { decisions affecting schools }\end{array}$ & 32 & 2.66 & 0.65 \\
\hline Creating positive opportunities for students & 32 & 3.28 & 0.58 \\
\hline $\begin{array}{l}\text { Following policy and legal requirements while administering the } \\
\text { educational program }\end{array}$ & 32 & 3.16 & 0.57 \\
\hline
\end{tabular}

Note: 4 = Distinguished, 3 = Proficient, 2 = Basic, 1 = Unsatisfactory

General Leadership. The last category had nine questions and was a "catch-all" for any questions that had not been previously covered, many of which were specific to the Indiana Content Standards. While the majority of means hovered around 3.00 for this category and all were in the "proficient" range, there were two questions that showed slightly lower means. Those questions were, "Recruiting and assigning staff" $(M=2.69, S D=0.97)$, and "Leading consensus for change" $(M=2.73, S D=0.84)$. A higher mean was observed on the question, "Protecting the rights of students, families, and faculty" $(M=3.27, S D=0.63)$. The overall mean for this category was 2.97 . These results are outlined in Table 7 . 
Table 7

General Leadership Questions - Superintendents' Mean Responses Regarding the Performanceof New Principals

\begin{tabular}{lccc}
\hline \multicolumn{1}{c}{ Question } & $n$ & $M$ & SD \\
\hline Recruiting and assigning staff & 32 & 2.69 & 0.97 \\
\hline Evaluating instructional staff & 33 & 3.00 & 0.75 \\
\hline Leading professional development and supporting faculty & 33 & 2.94 & 0.70 \\
\hline Delegating tasks and responsibilities & 33 & 2.94 & 0.75 \\
\hline Establishing priorities & 33 & 3.00 & 0.90 \\
\hline Establishing a culture of urgency for academic excellence & 33 & 3.03 & 0.77 \\
\hline Communicating with students, faculty, and parents & 33 & 3.12 & 0.99 \\
\hline Leading consensus for change & 33 & 2.73 & 0.84 \\
\hline Protecting the rights of students, families, and faculty & 33 & 3.27 & 0.63 \\
\hline
\end{tabular}

Note: 4 = Distinguished, $3=$ Proficient, $2=$ Basic, $1=$ Unsatisfactory

\section{Summary}

The purpose of this study was to investigate the effectiveness of Indiana's recently hired school administrators. This information is especially important for university faculty members in leadership education as it assists in assessing and improving administrative preparation programs and practices. Thirty-seven public school superintendents provided ratings for new principals on standards-based questions, which were clustered into seven categories. Descriptive statistics were utilized to examine superintendents' mean responses, creating a well-defined snapshot of current areas of strength and potential areas of growth for Indiana's new principals, thus providing implications for university educational leadership programs.

In summarizing results from broad to specific, the overall mean responses for the seven category (high to low) were: Integrity $(M=3.27)$, Culture, instruction and curriculum $(M=3.09)$, Context $(M=3.07)$, Vision $(M=3.01)$, General Leadership $(M=2.97)$, Management $(M=2.90)$, and Collaboration $(M=2.88)$. In terms of the individual questions that indicated the highest or lowest means, Table 8 summarizes these results by presenting the questions with the five highest means, and then the five lowest, as rated by the participating superintendent. 
Table 8

Survey Questions With the Five Highest and Lowest Mean Responses from Superintendents Regarding the Performance of New Principals

\begin{tabular}{|c|c|c|c|c|}
\hline Questions with highest mean responses & Category & $n$ & $M$ & $S D$ \\
\hline $\begin{array}{l}\text { 1. Modeling ethical behavior, fairness, and } \\
\text { reflective practice }\end{array}$ & Integrity & 32 & 3.44 & 0.50 \\
\hline $\begin{array}{l}\text { 2. Understanding the moral and legal consequences } \\
\text { of administrative decisions }\end{array}$ & Integrity & 32 & 3.38 & 0.66 \\
\hline 3. Creating positive opportunities for students & Context & 32 & 3.28 & 0.58 \\
\hline $\begin{array}{l}\text { 4. Protecting the rights of students, families, and } \\
\text { faculty }\end{array}$ & General & 33 & 3.27 & 0.63 \\
\hline 5. Understanding and promoting social justice & Integrity & 32 & 3.22 & 0.66 \\
\hline Questions With Lowest Mean Responses & Category & $n$ & $M$ & $S D$ \\
\hline $\begin{array}{l}\text { 1. Demonstrating financial management aligned } \\
\text { with school goals }\end{array}$ & Management & 33 & 2.45 & 0.87 \\
\hline $\begin{array}{l}\text { 2. Informing stakeholders of current local, state, } \\
\text { and national decisions affecting schools }\end{array}$ & Context & 32 & 2.66 & 0.65 \\
\hline 3. Recruiting and assigning staff & General & 32 & 2.69 & 0.97 \\
\hline 4. Developing leadership in others & Management & 33 & 2.73 & 0.88 \\
\hline 5. Leading consensus for change & General & 33 & 2.73 & 0.87 \\
\hline
\end{tabular}

Note: 4 = Distinguished, $3=$ Proficient, 2 = Basic, $1=$ Unsatisfactory

\section{Discussion}

In analyzing the responses from Indiana superintendents about the performance of their new principals, there was a sense that university administrator training programs are more effectively preparing school leaders than current popular rhetoric would lead us to believe. Superintendents consistently rated the principals in the "proficient" range. Several questions, especially in the category of Integrity, bordered on "distinguished." There was only one question that showed a mean response in the "basic" range, and that was, "Demonstrating financial management aligned with school goals." Overall, our results suggested that the superintendents perceived their new principals to be proficient school leaders.

In terms of areas that stood out as strengths, it was noteworthy that three of the top fiverated questions came from the Integrity category, including the individual question with the highest mean, "Modeling ethical behavior, fairness, and reflective practice." This question also 
recorded the lowest standard deviation (0.50). For every question in the Integrity category, the mean ratings were above 3.00, placing the new principals between "proficient" and "distinguished." Therefore, our results suggested that the category of Integrity, which corresponds with ELCC Standard number five and Indiana Standard number three, was a strong area for Indiana's newly hired principals, as perceived by our superintendent respondents. We found these results encouraging because Integrity is considered foundational in leadership development (Pijanowski, 2007; Rebore, 2014; Shapiro \& Stefkovich, 2001). As explained by Colonel Art Athens in a recent presentation, integrity is core and absolutely fundamental for those who strive to be effective leaders (Athens, 2013).

Two other categories that emerged as strong areas, although not as robust as Integrity, were Culture, Instruction and Curriculum (ELCC Standard two, Indiana Content Standards two and five) and Vision (ELCC Standard one, Indiana Content Standard two). On every question except one, mean ratings placed principals at or slightly above "proficient," in these two categories, suggesting that the superintendents viewed the principals' performance favorably in these areas.

Categories potentially considered areas for development were Collaboration, which aligns with ELCC Standard four and Indiana Content Standard four; and Management, which corresponds with ELCC Standard three and Indiana Content Standard one. Although the mean responses for all questions in Collaboration fell in the "proficient" range, every mean was below 3.00. In addition, the overall mean for Collaboration was the lowest of any category, suggesting that Collaboration was an area in which the superintendents did not perceive the principals to be as proficient as the other categories.

The Management category had two questions with lower means and those pertained to financial management and developing leadership in others. The question on developing leadership in others was in the "proficient" range, yet was the fourth lowest mean of all questions. The finance question was the lowest mean of all questions and fell in the "basic" range, suggesting an area in which the superintendents had diminished confidence in their new principals.

Implications and Recommendations for Practice

The results of this study have important implications as they revealed that except for one question, "Demonstrating financial management aligned with school goals," the superintendent participants viewed their new principals as being proficient in terms of both national ELCC Standards and state-level Indiana Standards. Therefore, contrary to some viewpoints previously discussed implying that university programs are seriously lacking (e.g., Hess and Kelly, 2005; LaPointe \& Davis, 2006; Levine, 2005; Murphy, 2001), our results implied that newly hired principals, as perceived by their superintendents, had been well prepared by the university and that these individuals were performing successfully in their schools. In short, our results suggest that university administrative training programs are providing the necessary skills and knowledge, per the ELCC and Indiana Content Standards, needed for new school leaders to be proficient on the job.

Nevertheless, our study also reveals several areas for growth, specifically collaboration, developing leadership in others, and financial management. We suggest that university faculty 
in educational leadership departments around the state consider each of these areas in light of their current curriculum, course content, instruction, and activities for administrator training. Furthermore, we recommend that the area of "financial management aligned with school goals," be considered a priority focus area for improvement. We found the results of the financial management question troubling because in the last few years, the state of Indiana has made substantial changes to both the school funding process and the school funding formula (Hiller \& Spradlin, 2010; Spradlin, Robbins, Popely, \& Lara, 2011). Some of the changes were intended to lessen school funding inequities around the state and others were made to reduce local property taxes; however, in many cases public school districts are now receiving decreased levels of revenue (Adamson, 2013; Jarman \& Boyland, 2011). Due to the many state-level funding changes, as well as Indiana's slow recovery from the Great Recession, public school finance has become a hot topic in the state.

It appears from our study that superintendents would like their new principals to have a better understanding of emerging financial issues and to be able to effectively prioritize buildinglevel fiscal resources aligned with school goals. Therefore, an important recommendation for university training in general is the need to deliver the most up-to-date information to candidates on school fiscal issues and funding changes, as well as to provide candidates the opportunity to practice developing building-level budgets based on school improvement goals.

In addition to the above, we recommend that currently practicing principals be offered professional development opportunities regarding school finance and other evolving areas. Once candidates have graduated from their university programs, it may be difficult for them to remain current regarding important changes taking place in education in Indiana and around the nation. Therefore, our results indicated that periodic "refreshers" in finance and other areas would be beneficial for principals, and in all likelihood, superintendents would support this professional development.

\section{Limitations}

This study has several limitations. One limitation is that the survey response rate was only $17 \%$ of the superintendents in the state. Although this is considered acceptable for electronic survey research, it limits the generalizability of results. Therefore, the reader is advised to view these results as exploratory.

A second potential limitation is that we cannot identify which university the buildinglevel administrator attended. We wanted to focus on the aspect of shared preparatory standards across the state, not individual programs; therefore, this was purposeful. Regardless, we realize that superintendents affiliated with certain universities might have responded at higher rates. In addition, even though we stated in the cover letter and on the survey instructions that this was a study about Indiana administrator preparation, it is conceivable that a superintendent might have completed the survey for a principal who attended an out-of-state training program and then recently received reciprocal licensure in Indiana. Consequently, while it is possible that a superintendent in the survey commented on a principal prepared in another state, because of our cover letter and instructions, we feel reasonably confident that the data is reflective of candidates who completed a preparation program in our state. 
Finally, although all the major university administrative training programs in Indiana are using the ELCC and Indiana Content Standards, we realize that we cannot assume that all programs in the state are covering the same content or using the same approaches. However, there is a positive working relationship among the university faculty in school leadership education programs around the state, and we feel optimistic that upon sharing our results, constructive discussions will occur.

\section{Need for Further Research}

While the results of our study were encouraging for Indiana's university administrative preparation programs, there is much work to be done and there is a call for further research. Follow-up studies of Indiana's superintendents in terms of their perceptions of new principal effectiveness are needed in order to compare results over time. In addition, further studies encompassing wider geographic areas and using larger sample sizes are necessary in order to better understand the preparatory needs of new school leaders and their additional needs for professional development and support once they become principals.

In summary, this study has significance because it increases our understanding of the effectiveness of shared standards-based preparation of school leaders in Indiana. These data will inform current practice and will also be available for future comparison purposes as the universities in Indiana continue to strive for improved administrator preparatory programs.

\section{References}

Adamson, M. (2013, July). Financing Increasing Expectations: Dollars \& Sense. The Journal. The Indiana School Board Association, Summer 2013, 13-15.

Andenoro, A. C., Allen, S. J., Haber-Curran, P., Jenkins, D. M., Sowcik, M., Dugan, J. P., \& Osteen, L. (2013). National Leadership Education research agenda 2013-2018: Providing strategic direction for the field of leadership education. Retrieved from Association of Leadership Educators website: http://leadershipeducators.org/ResearchAgenda.

Andenoro, A. C. (2013). National Leadership Education research agenda: Strategic priorities and deepened perspectives. Journal of Leadership Education, 12(3), 1-9. Retrieved from http://www.leadershipeducators.org/JOLE12-3

Athens, A. (2013, November). The Fundamentals of Extraordinary Leadership. Presentation at the Indiana Association of School Principals Annual Convention, Indianapolis, IN.

Berman, P., \& McLaughlin, M. (1978). Implementation of educational innovation. The Educational Forum, (40), 347-370.

Branch, G. F., Hanushek, E. A., \& Rivkin, S. G. (2009, December). Estimating principal effectiveness. Calder Working Paper 32. Washington, DC: The Urban Institute.

Branch, G. F., Hanushek, E. A., \& Rivkin, S. G. (2013, Winter). School leaders matter. Education Next. 63-69. 
Brookover, W. B., \& Lezotte, L. W. (1977). Changes in school characteristics coincident with changes in school achievement, East Lansing, MI: Michigan State University, College of Urban Development.

CAEP (2013). Council for the Accreditation of Educator Preparation. History of CAEP. Retrieved from http://caepnet.org

Council of Chief State School Officers (CCSSO) 2012. ISLLC Standards for District-Level School Leaders. Interstate School Leaders Licensure Consortium. Retrieved from http://www.ccsso.org

Cowie, M., \& Crawford, M. (2007). Preparation - still an act of faith? School Leadership and Management, 27(2), 129-146.

Cuban, L. (1988). The managerial imperative and the practice of leadership in schools. Albany, NY: SUNY Press.

Darling-Hammond, L., LaPointe, M., Meyerson, D., Orr, M. T., \& Cohen, C. (2007). Preparing school leaders for a changing world: Lessons from exemplary leadership development programs. Stanford, CA: Stanford University, Stanford Educational Leadership Institute.

Duke, D. L., Grogan, M., Tucker, P. D., \& Heinecke, W. F. (2003). Educational leadership in an age of accountability. Albany, NY: State University of New York Press.

Edmonds, R. (1979). Effective schools for the urban poor. Educational Leadership (October) 1524.

Educational Leadership Constituent Council (2011). Educational leadership program standards, 2011 ELCC Building-Level. National Policy Board for Educational Administration. Retrieved from http://npbea.org/wp-content/uploads/2012/06/ELCC-Building-LevelStandards-2011.pdf

Farkas, S., Johnson, J., Duffett, A., Foleno, T., \& Foley, P. (2001). Trying to stay ahead of the game: Superintendents and principals talk about school leadership. Washington, D.C.: Public Agenda.

Frye, B., O'Neill, K., \& Bottoms, G. (2006). Challenge to lead series: Schools can't wait: Accelerating the redesign of university principal preparation programs. Atlanta, GA: Southern Regional Education Board.

Hallinger, P. (2003). Leading educational change: reflections on the practice of instructional and transformational leadership. Cambridge Journal of Education, 33, 329-351.

Hallinger, P., \& Heck, R. H. (1998). Exploring the principal's contribution to school effectiveness: 1980-1995. School Effectiveness and School Improvement, 9(2), 157-191.

Haller, E. L., Brent, B. O., \& McNamara, J. H. (1997, November). Does graduate training in educational administration improve America's schools? Phi Delta Kappan, 79, 222-227. 
Harvey, J., \& Holland, H. (2012). The principal as leader: Guiding schools to better teaching and learning. New York, NY: Wallace Foundation.

Hess, F. M., \& Kelly, A. P. (2005). An innovative look, a recalcitrant reality: The politics of principal preparation reform. Educational Policy, 19, 155-180.

Hill, Peter, W. (2002). What principals need to know about teaching and learning. In Marc S. Tucker \& Judy B. Codding (Eds.). The principal challenge: Leading and managing schools in an era of accountability (pp. 43-75). San Francisco, CA: Jossey-Bass.

Hiller, S. C., \& Spradlin, T. E. (2010). School referenda in Indiana. Education policy brief, 8(2). The Center for Evaluation and Education Policy. Retrieved from http://ceep.indiana.edu/projects/PDF/PB_V8N5_Winter_2010_EPB.pdf

Horng, E., Kalogrides, D., \& Loeb, S. (2009, December). Principal preferences and the unequaldistribution of principals across schools. Calder Working Paper 36. Washington D.C.: The Urban Institute. Retrieved from www.urban.org.

Horng, E., \& Loeb, S. (2010, November). New thinking about instructional leadership. Phi Delta Kappan, 92. 66-69.

Indiana Department of Education (2013a). Administrator licensing, evaluation, and Accountability information. Located under Administrator tab. Retrieved from http://www.doe.in.gov/

Indiana Department of Education (2013b). Superintendent addresses, emails, and labels. Located under Data Center tab. Retrieved from http://www.doe.in.gov/

Indiana State Government Website (2009). Functional classification maps and urban area boundary. Indiana Department of Transportation. Retrieved from http://dotmaps.indot.in.gov/apps/PlanningDataViewer/FC_Maps/FC_listing.asp

Jarman, D. W. \& Boyland, L. G. (2011). The impacts of budget reductions on Indiana's schools. Current Issues in Education, 14(2). Retrieved from http://cie.asu.edu/ojs/index.php/cieatasu/issue/view/13

Lapointe, M., \& Davis, S. (2006, November) School Leadership Study Developing Successful Principals: Exemplary Programs Produce Strong Instructional Leaders. Paper presented at the University Council for Educational Administration Annual Conference, San Antonio, TX.

Leithwood, K., Seashore, L. K., Anderson, S., \& Wahlstrom, K. (2004). How leadership influences student learning. New York, NY: The Wallace Foundation.

Levine, A. (2005). Educating school leaders. New York, NY: Teachers College Press.

Marzano, R. J., Waters, T., \& McNulty, B. A. (2005). School leadership that works: Fromresearch to results. Alexandria, VA, Association for Supervision and Curriculum Development. 
Milstein, M. M., Bobroff, B. M., \& Restine, L. N. (1991). Internship programs in educational administration. New York, NY: Teachers College Press, Columbia University.

Murphy, J. (1992). The landscape of leadership preparation: Reframing the education of school administrators. Newbury Park, CA: Corwin Press.

Murphy, J. (2002). Reculturing the profession of educational leadership: New blueprints: In J.

Murphy (Ed.). The educational challenge: Redefining leadership for the $21^{\text {st }}$ century (pp. 65-82). Chicago, IL: National Society of Education.

Murphy, J., \& Hallinger, P. (1987). New directions in the professional development of school administrators: A synthesis and suggestions for improvement. Approaches to Administrative Training in Education. Albany, NY: SUNY Press, 245-273.

Murphy, J., \& Vriesenga, M. (2004). Research on school leadership preparation in the United States: an analysis. School Leadership and Management, (26)2, 183-195.

Norton, J. (2002). Preparing school leaders: It's time to face the facts. Southern Regional Education Board. Atlanta, Georgia.

Pijanowski, J. (2007). Defining moral leadership in graduate schools of education. Journal of Leadership Education, (6)1, 1-13. Retrieved from http://www.leadershipeducators.org/JOLE6-1

Rebore, R. W. (2014). The ethics of educational leadership ( $2^{\text {nd }}$ ed.). Upper Saddle River, NJ: Pearson.

Rice, J. K. (2010, April). Principal effectiveness and leadership in an era of accountability: What research says. Calder Brief 8. Washington, D.C.: The Urban Institute. Retrieved from www.urban.org.

Rousmaniere, K. (2007, February). Presidential address: Go to the principal's office: Toward a social history of the school principal in North America. History of Education Quarterly 47(1), 1-22.

Shapiro, J. P., \& Stefkovich, J. A. (2001). Ethical leadership and decision making in education. Mahwah, NJ: Lawrence Erlbaum Associates, Inc., Publishers.

Sheehan, K. (2001). E-mail survey response rates: A review. Journal of Computer-Mediated Communication, 6(2). Retrieved from http://jcmc.indiana.edu/vol6/issue2/

Spradlin. T., Robbins, H., Popely, J., \& Lara, L. (2011, November). Understanding the history of Indiana school finance and the current funding formula. Presentation at the fall 201 conference of the Indiana Association of Public School Superintendents and Indiana School Board Association. Power Point slides retrieved fromhttp://www.docstoc.com/docs/158896069/2011_IAPSS_ISBA_Fall_Conference_Sc hool 
The Wallace Foundation. (2013, January). The school principal as leader: Guiding schools to better teaching and learning. New York, NY: Author. Retrieved from www.wallacefoundation.org.

Tucker, P. D., Henig, C. B., \& Salmonowicz, M. J. (2005). Learning outcomes of an educational leadership cohort program. Educational Considerations, 32(2), 27-35.

U.S. Census Bureau Website (2013). Data from latest census (2010). Retrieved from http://www.census.gov/

Young, M. D., \& Mawhinney, H. (Ed.). (2012). The research base supporting the ELCC standards. University Council for Educational Administration.

\section{Author Biographies}

Lori Boyland is an Assistant Professor in the Department of Educational Leadership at Ball State University. Before joining the faculty at Ball State in 2008, Dr. Boyland served as a public school teacher and principal for 22 years in the state of Indiana.

Lynn Lehman is an Assistant Professor in the Department of Educational Leadership at Ball State University. In 2009, Dr. Lehman joined the Ball State faculty after serving as a teacher, principal, central office administrator, and superintendent for 39 years in the public schools of Indiana.

Shawn Sriver is the Accreditation and Assessment Coordinator at Ball State University. Before joining Ball State University in 2009, Mr. Sriver served in the Indiana Department of Education for 17 years, including four years as the Director of the Division of Professional Standards, and as a public school teacher for five years. 